\title{
Economic and Financial Assessment of Solar-Powered Irrigation
}

\author{
Lana Mousa Abu-Nowar ${ }^{1}$ \\ ${ }^{1}$ Green Economy and Gender Research Department, Economic and Social Studies Research Directorate, \\ National Agricultural Research Center (NARC), Jordan \\ Correspondence: Lana Mousa Abu-Nowar, Green Economy and Gender Research Department, Economic and \\ Social Studies Research Directorate, National Agricultural Research Center (NARC), Jordan. E-mail: \\ lanaabunowar@yahoo.com
}

\author{
Received: January 15, 2020 \\ Accepted: February 17, 2020 \\ Online Published: March 15, 2020 \\ doi:10.5539/jas.v12n4p185 \\ URL: https://doi.org/10.5539/jas.v12n4p185
}

\begin{abstract}
This paper aimed at assessing the economic and financial viability of solar-powered irrigation of tomato crop in Jordan Valley. Data were collected from 16 tomato farms that use solar-powered irrigation system. Another 16 farms with diesel-powered irrigation system was investigated for comparative reasons. Descriptive statistics, Cost Function Analysis (CFA), Life-cycle Cost Analysis (LCCA), Water Productivity (WP) and the financial indicators of Net Present Value (NPV), Internal Rate of Return (IRR), Payback Period (PP) and Benefit to Cost Ratio (B/C) were the main economic and financial analytical tools used in this study. The results of the study revealed that costs of inputs, labor costs and equipment and maintenance costs have had a lower adverse impact on the total revenues level when using solar-powered irrigation system. The results also indicated the preference of the investigated financial indicators (NPV, IRR, PP and B/C ratio) when solar-powered irrigation is used compared to diesel-powered irrigation. The results also revealed a lower cost of life of the farm under the use of solar-powered irrigation. The governmental policies and programs should be directed toward the concepts of renewable energy in general and solar energy uses in agriculture in particular. Special agricultural extension plans in training and capacity building of farmers and extension workers on the use of solar energy in irrigation of agricultural crops should be developed. Cooperation in the fields of solar energy between the Ministry of Agriculture and related parties such as the Royal Scientific Society and the Ministry of Energy should be initiated to conduct specialized researches in the fields of solar energy use in agriculture.
\end{abstract}

Keywords: solar-powered irrigation, Jordan Valley, cost function analysis, life-cycle cost, financial indicators

\section{Introduction}

People are always looking for new sources of energy to cover their growing needs in applications of the advanced life they live. Fossil fuel, the major source of power, is depleting, so other sources of energy are needed to be developed (Mohammad, 2014). Solar energy applications have more attention to substitute the fossil fuel in Jordan. The increasing energy demand has brought challenges to Jordan due to country's limited resources. One of the most important energy applications to be considered in this manner is agriculture. Solar energy is used in many agricultural processes, including solar sterilization of soil, drying of crops, heating and cooling of water, desalination of water for drinking and wastewater treatment. The use of solar energy in agriculture is becoming increasingly popular and the energy produced from this renewable source can be used on the farm providing the farmer with an additional income. One of the most important uses of solar energy in the agricultural sector is generating electricity to irrigate agricultural crops, especially in view of the increasing costs of electricity consumption using fossil fuels to generate electricity (Alnogrouch, 2005). During the last decade, irrigating agricultural crops through solar-powered irrigation pumps is an emerging practice in Jordan. Solar-powered irrigation pumps need little maintenance, and their operating life may be more than 20 years, they are easy to install, and do not pollute the environment. On the other hand, the disadvantages of using solar energy in irrigation are that its capital cost is high, energy storage must be ensured to take advantage of it during the period of solar radiation, and its maintenance requires skilled technicians. Diesel-powered irrigation pumps are characterized by low capital costs, fast and easy installation and widespread use. Their disadvantages include their high operational costs and maintenance costs, short life span, noise and environmental pollution (Neil, 2012).

Worldwide, $15 \%$ of total energy consumption in crop production is for pumping irrigation water (Dursun \& Ozden, 2012). Cost of irrigating many agricultural crops (mainly vegetables) in Jordan Valley by diesel-powered 
irrigation pumps is a major component of the capital and operational costs of production using traditional methods. Therefore, other means of power sources should be sought (MoA, 2014). Many researches showed that the use of a solar pump in pumping irrigation water is more profitable than using a diesel pump (Hossain et al., 2015; Sharif, 2013; Khair, 2015; Narale et al., 2013; Bakry \& Jasem, 2013; Seham \& Imad, 2012; Neil, 2012). Due to its economic and technical feasibility, especially in terms of cost compared to other traditional sources of energy, solar-powered irrigation pumps are now of the most important applications of water pumping systems to irrigate agricultural crops. This technology is now used on a commercial scale in different countries in the world (Achkour, 2015).

Tomato is a major crop in Jordan. It is in the forefront of cultivated area compared to other vegetables according to the 2014 Department of Statistics report. The total area planted by tomato in 2014 was 251604 dunums, of which 164467 dunums in Jordan Valley alone. The production of this crop for the same year was about 1493629 tons, including 1143773 tons in Jordan Valley. Jordan is one of the top ten countries in the production and export of tomatoes worldwide. According to the year 2014 Department of Statistics (DoS) records, the list of exported vegetables and fruits is $70 \%$ of the total exports of 465 thousand tons exported to various international markets, mainly to the Arab Gulf States and Europe (DoS, 2014).

The present study introduces a comparative economic and financial assessment for two systems of water pumping; PV system, and Diesel unit system to irrigate tomato crop.

\section{Solar-Powered Irrigation}

Because of its climate and geographical location, Jordan is capable of exploiting the sun's rays. It is located within the so-called solar belt states, which are between the latitudes 35 North and 35 South. The number of days on which the sun rises on Jordan's land is over 300 days a year at an average of 8 hours per day and at an elevation of 83 degrees in summer (Jordan Renewable Energy Association, 2011). Figure 1 shows the distribution of solar radiation in Jordan. From the figure, it is clear that higher solar radiation levels can strongly supports the use of solar energy in Jordan. The perfect meteorological conditions and land space are available, where solar pumping could supply freshwater for drinking, industry, and for agriculture in Jordan.

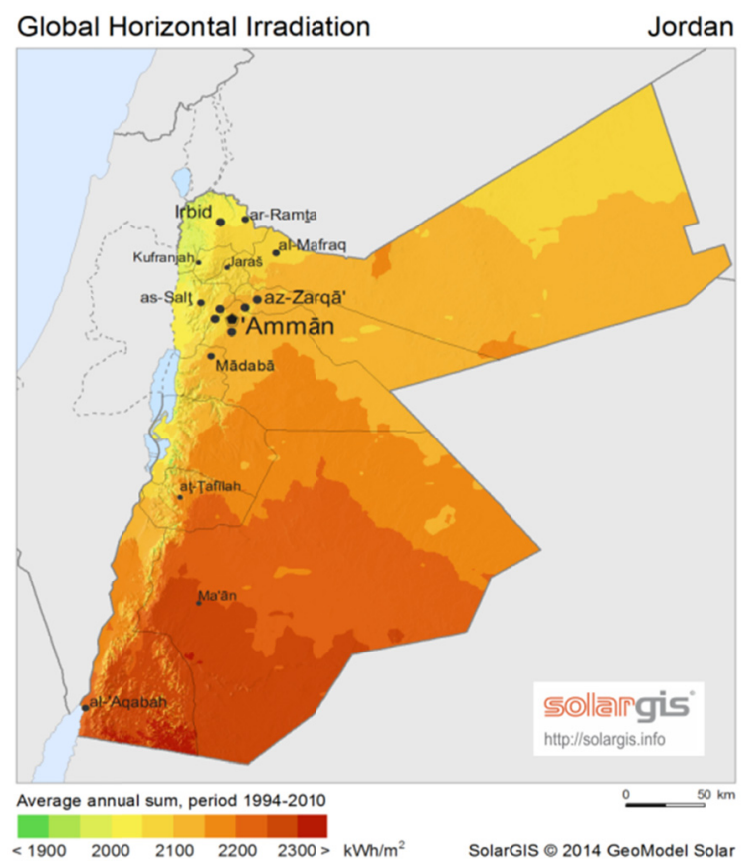

Figure 1. Distribution of solar radiation in Jordan

Source: https://solargis.com/products/maps-and-gis-data/free/download/jordan.

Sun is a major source of energy which can be found all over the world but the energy produced is different region by region depending on meteorological condition and demand for energy service. In recent years the development of renewable energy sources is being popular in Jordan due to the increasing fuel cost and doubtful 
availability of electricity. Transforming solar energy into electricity through photovoltaic (PV) technology is the dominant application to develop renewable energy sources. This method is based on a technique using solar panels containing electrochemical cells that convert sunlight into electrical energy. Due to the continuous decrease in its cost, the presence of several competing companies in the market and the existence of researches related to its efficiency this technology began to spread widely in many countries (Curtis, 2010). Due to High Grade energy output the PV cells are used to run the electrical equipments directly. One of the remarkable applications of solar PV is to provide electricity to Agricultural water pumps. Many research studies were carried out to investigate the performance of water pumps based on solar energy (Campana et al., 2013, 2015; Korpalea et al., 2016). A photovoltaic water pumping system (PVWPs) is a combination of different components connected together to fulfill the water requirement. Figure 2 shows illustration of simple PV system. The power from sun converted by PV module is transferred to the pump which in turn delivers water to where it is needed. The main components of the system are PV array, controller or inverter (s) and motor-pump unit.

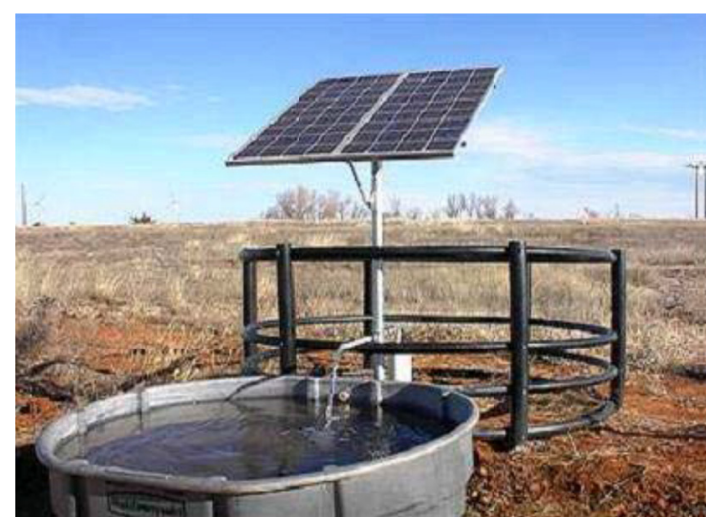

Figure 2. Simple PV system

Source: Curtis (2010).

Solar powered pumping systems are capable of delivering water from rivers and wells in volumes up to 9000 $1 /$ minute (Tietjen et al., 2008). Solar pumping systems costs from $22-56 \%$ of diesel pumps cost and can achieve a payback over diesel engine operated pump little as 2 years (NAMREP, 2006). Abu-Aligah (2001) reported that in locations where electricity is not available photovoltaic pumping system is a good option for irrigating crops and supplying drinking water. Hahn (2000) stated that in regions with high insolation levels, photovoltaic pumping systems were technically suitable for use, beneficial for the environment and were able to yield cost advantages over diesel engine driven pumps. With the reduction of price of solar panel and electronic components solar power is now an economically viable option for irrigation.

\section{Materials and Methods}

\subsection{Study Area}

The part of Jordan Valley covered by this study extends from Northern Shouneh area to the Southern Shouneh area near the Dead See. Jordan Valley (Figure 3) is a low-lying strip that extends along Jordan's west border from Northern Jordan near Lake Taiberia to southern Jordan near Aqaba. The prevailing subtropical climate in the Jordan Valley and fertile soil allows for year around cultivation especially vegetables in winter. About $70 \%$ of Jordan's production of fruit and vegetables is from the Jordan Valley. Crops planted in the different agro climatic zones in the Jordan Valley are field crops, vegetables, fruit trees, banana, citrus, green house vegetables, and dates. The valley is a long and narrow trough; it is $105 \mathrm{~km}$ (65 miles) long with a width averaging $10 \mathrm{~km}$ (6.2 miles) with some points narrowing to $4 \mathrm{~km}$ ( 2.5 miles) over most of the course before widening out to a 20 $\mathrm{km}$ (12 miles) delta when reaching the Dead Sea. The valley is bordered by high, steep, escarpments with the difference in elevation between the valley floor and the surrounding mountains varying between $1,200 \mathrm{~m}$ to $1,700 \mathrm{~m}$ (Salameh, 2001). 


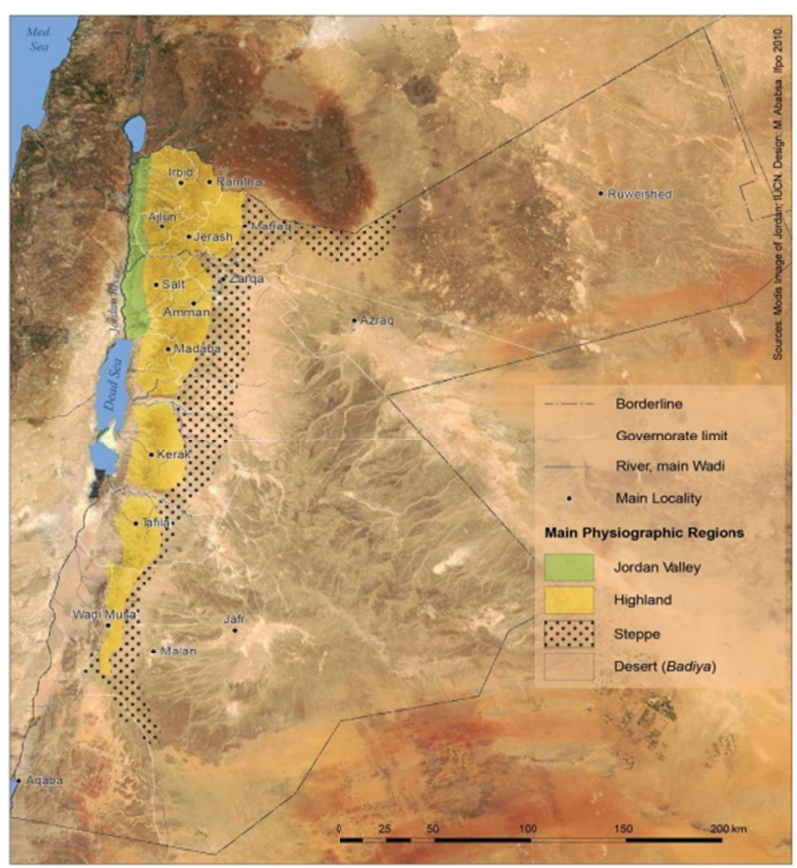

Figure 3. Study area (in green)

\subsection{Population and Sample}

The population of the study consists of two types of tomato farms, the first type use solar energy for water pumping to irrigate tomato (16 farms), and the second use diesel as a source of energy for water pumping. Both types of farms are located in three of the most important vegetables production areas in Jordan Valley (North Shouneh, Dair Alla, and Southern Shouneh). Due to the limited number of farms that use solar energy for water pumping, all these farms were considered in the analysis. The total number of farms using solar energy in Northern Shouneh is 5, in Dair Alla is 5 and in South Shouneh is 6 . To achieve the objectives of the study, a comparative economic and financial assessment was conducted between the 16 farms using solar energy for water pumping and other 16 farms using diesel as energy source for water pumping to irrigate tomato. Table 1 shows the distribution of the investigated farms according to study areas.

Table 1. Distribution of the investigated farms according to the study areas

\begin{tabular}{llll}
\hline Area & Solar-powered pumps farms & Diesel-powered pumps farms & Total \\
\hline Northern Shouneh & 5 & 5 & \\
Dair Alla & 5 & 5 & \\
Sourthern Shouneh & 6 & 6 & 32 \\
Total & 16 & 16 & \\
\hline
\end{tabular}

Source: Field survey.

\subsection{Data Collection}

To obtain information from respondents, a well-structured questionnaire was designed. The questionnaire included items related to the cultivated areas, fixed and variable production costs (cost of labor, cost of equipment and materials, cost of fuel in the case of conventional energy), production quantities, revenue and other information necessary to achieve objectives of the study. The questionnaire was presented to relevant specialists and technicians to be evaluated. The questionnaire accordingly was modified. Secondary data sources included Department of Statistics (DoS), Ministry of Agriculture (MoA) and other agricultural related agencies. 


\subsection{Data Analysis}

Descriptive statistics, Cost Function Analysis (CFA), Life-cycle Cost Analysis (LCCA), Water Productivity (WP) and the financial indicators of Net Present Value (NPV), Internal Rate of Return (IRR), Payback Period (PP) and Benefit to Cost Ratio (B/C) were the main analytical tools used in this study.

\subsubsection{Descriptive Statistics}

Descriptive statistics are brief descriptive coefficients that summarize a given data set, which can be either a representation of the entire population or a sample of it. Descriptive statistics are broken down into measures of central tendency and measures of variability, or spread. The main descriptive indicators were estimated for both types of the investigated farms.

\subsubsection{Cost Function Analysis}

Cost analysis helps allocation of resources among various alternatives. Cost function summarizes all of the economically relevant information about the process of transforming inputs into outputs. Cost functions were estimated, average cost functions were derived for both types of the investigated farms to determine the optimum size of production for allocation of resources to be efficient.

\subsubsection{Life-Cycle Cost Analysis}

Life-cycle cost analysis (LCCA) is a tool to determine the most cost-effective option among different competing alternatives to purchase, own, operate, maintain and, finally, dispose of an object or process, when each is equally appropriate to be implemented on technical grounds. This Life Cycle Costing Tool has been developed to assist asset managers in decision making based on performing a systematic assessment of the life cycle costs of selected assets. The initial capital outlay cost is usually clearly defined and is often a key factor influencing the choice of asset given a number of alternatives from which to select. The process of identifying and documenting all the costs involved over the life of an asset is known as Life Cycle Costing (LCC). LCC was conducted for both types of the investigated farms. The formula to calculate LCC is as follows:

$$
\text { LCC }=\text { Investment costs }+ \text { Present value of future costs of operating, maintenance and replacement costs (1) }
$$

\subsubsection{Water Productivity (WP)}

Water productivity is generally defined as crop yield per cubic meter of water consumption for irrigated areas. The concept of water productivity (WP) is offered by Kijne et al. (2003) as a robust measure of the ability of agricultural systems to convert water into food.

The productivity of the cubic meter of water was calculated for both types of the investigated farms. The following formula was used:

$$
\text { Productivity }=\text { Average production }(\mathrm{kg} / \text { dunum}) / \text { Average quantity of water used }\left(\mathrm{m}^{3} /\right. \text { dunum) }
$$

\subsubsection{Financial Indicators}

To determine the financial viability of using solar-powered irrigation, the Net Present Value (NPV), Internal Rate of Return (IRR), payback period (PP) and Benefits to Costs (B/C) ratio for both types of the investigated farms were calculated. The feasibility of the investigated farms was analyzed at a discount rate of $12 \%$ over a 10 years period for both NPV and IRR.

\section{(1) NPV}

Net Present Value (NPV) is the difference between the present value of cash inflows and the present value of cash outflows. NPV is used in capital budgeting to analyze the profitability of a projected investment or project. The NPV was calculated as follows:

$$
\mathrm{NPV}=\mathrm{R}_{\mathrm{i}} /(1+\mathrm{i})^{\mathrm{t}}
$$

Where, t: time, i: discount rate; $\mathrm{R}_{\mathrm{i}}$ : net cash flow.

(2) IRR

Internal rate of return (IRR) is the interest rate at which the net present value of all the cash flows (both positive and negative) from a project or investment equal zero. IRR is used to evaluate the attractiveness of a project or investment. If the IRR of a new project exceeds a company's required rate of return, that project is desirable. If IRR falls below the required rate of return, the project should be rejected. The IRR can be mathematically calculated as follows: 


$$
\mathrm{CF}_{0}+\frac{\mathrm{CF}_{1}}{(1+\mathrm{r})^{1}}+\frac{\mathrm{CF}_{2}}{(1+\mathrm{r})^{2}}+\frac{\mathrm{CF}_{3}}{(1+\mathrm{r})^{3}}+\frac{\mathrm{CF}_{\mathrm{n}}}{(1+\mathrm{r})^{\mathrm{n}}}=0
$$

Where, CF: cash flow in the last period being $n$, and $r$ is the internal rate of return to be calculated.

(3) PP

Payback period in capital budgeting refers to the period of time required to recoup the funds expended in an investment, or to reach the break-even point. For example, a $\$ 1000$ investment made at the start of year 1 which returned $\$ 500$ at the end of year 1 and year 2 respectively would have a two-year payback period.

(4) B/C Ratio

$\mathrm{B} / \mathrm{C}$ ratio is the ratio of the benefits to costs of an enterprise expressed in monetary basis. It is the ratio of total value of benefits to the total value of the costs. A reliable measurement to accept the investment is when $\mathrm{B} / \mathrm{C}$ ratio greater than or equal to one.

\section{Results and Discussion}

\subsection{Descriptive Statistics}

Averages of Total Returns (TR), Quantities produced (Q), Productivity of land unit (P) which is Dunum (1000 $\mathrm{m}^{2}$ ), Cost of Labor (L), Cost of Equipment and Maintenance (EM), Cost of other Inputs (OI) were calculated for both the solar-powered irrigation farms and diesel- powered irrigation farms. Table 2 shows the results of these calculations.

Table 2. Descriptive statistics of the investigated farms:

\begin{tabular}{lll}
\hline Item & Average in Solar-powered pumps farms & Average in Diesel-powered pumps farms \\
\hline TR (JDs/Year) & 2039 & 1861 \\
$\mathrm{Q}\left(\mathrm{Kgs} / 1000 \mathrm{~m}^{2}\right)$ & 6528 & 6191 \\
$\mathrm{P}\left(\mathrm{Kgs} / 1000 \mathrm{~m}^{2}\right)$ & 192 & 176 \\
$\mathrm{~L}(\mathrm{JDs} /$ Month $)$ & 149 & 184 \\
EM (JDs/Year) & 452 & 488 \\
OI (JDs/Year) & 201 & 224 \\
\hline
\end{tabular}

Source: Statistical analysis.

Table 2 shows that the averages of TR, Q and P are higher in solar-powered farms compared to those in diesel powered farms by almost $10 \%, 5 \%$ and $9 \%$ respectively. The table also indicates that the costs of labor, equipment and maintenance and other inputs are lower in solar-powered farms compared to those in diesel powered farms by almost $19 \%, 7 \%$ and $10 \%$ respectively. These results confirm the fact that using solar-powered pumps to irrigate tomato in study area is economically efficient than using diesel-powered pumps. Higher returns, production and productivity as well as lower costs were achieved. These results are in line with the results achieved by Hahn (2000), Hossain et al. (2015), Sharif (2013), and Khair (2015) that showed that the use of a solar pump in pumping irrigation water is more profitable than using a diesel pump.

\subsection{Cost function Analysis}

Cost functions were estimated for both solar-powered farms and diesel-powered farms, average cost functions were derived for both types of investigated farms to determine the optimum size of production for allocation of resources to be efficient. Table 3 shows the results of cost functions analysis.

Table 3. Cost functions analysis

\begin{tabular}{lll}
\hline Function & Solar-powered pumps farms & Diesel-powered pumps farms \\
\hline TC & $0.3318 \mathrm{X}-0.0009 \mathrm{X}^{2}+0.000000071 \mathrm{X}^{3}$ & $0.814 \mathrm{X}-0.0011 \mathrm{X}^{2}+0.000000094 \mathrm{X}^{3}$ \\
ATC & $0.3318-0.0009 \mathrm{X}+0.000000071 \mathrm{X}^{2}$ & $0.814-0.0011 \mathrm{X}+0.000000094 \mathrm{X}^{2}$ \\
\hline
\end{tabular}

Source: Statistical analysis.

Benefiting from the average costs functions, the optimum size of production level was determined for both solar-powered farms and diesel-powered farms. The optimum size of production level for solar-powered pumps 
farms was $6338 \mathrm{kgs}$ while this size for diesel-powered pumps farms was $5851 \mathrm{kgs}$. It is clear and expected, due to the higher rate of production using solar-powered pumps, that the optimum size of production level in solar-powered pumps farms was higher than that for diesel-powered pumps farms. The average cost of production using average cost function can be tracked to show the optimal production level where per-unit production cost is lowest and therefore profit margin is the highest. This level was 6338 and $5851 \mathrm{kgs}$ for solar-powered farms and diesel-powered farms respectively. These results are in line with the resuls obtained by Narale et al. (2013), and Bakry and Jasem (20130).

\subsection{Life-Cycle Cost (LCC) Analysis}

LCC was conducted for the solar-powered pumps farms as well as for the diesel-powered pumps farms. Table 4 shows the results of LCC analysis.

Table 4. LCC analysis

\begin{tabular}{lll}
\hline Item & Solar-powered pumps farms & Diesel-powered pumps farms \\
\hline Investment Costs (JDs) & 3800 & 2500 \\
Operating, maintenance and replacement costs (JDs) & 10105.89 & 12447.81 \\
LCC Value (JDs) & 13905.89 & 14947.81 \\
\hline
\end{tabular}

Source: Statistical analysis.

Table 4 shows costs involved over the life of both the solar-powered pumps farms and diesel-powered pumps farms. As shown in the table LCC value for solar-powered pumps farms is less than that for diesel-powered pumps farms by almost 1000 JDs (7.5\%). The results showed in table 4 confirm importance of solar-powered pumps in reducing costs over farm assets life cycle that needs to be considered in making the right choice for asset investment. Achkour (2015) derived similar conclusions.

\subsection{Water Productivity (WP)}

The productivity of the cubic meter of water was calculated for both the solar-powered pumps farms and the diesel-powered pumps farms. Table 5 shows the results of these calculations.

Table 5. WP analysis

\begin{tabular}{lll}
\hline Item & Solar-powered pumps farms & Diesel-powered pumps farms \\
\hline Average Production $\left(\mathrm{Kgs} / 1000 \mathrm{~m}^{2} /\right.$ Year $)$ & 6528 & 6191 \\
Average quantity of water used $\left(\mathrm{m}^{3} /\right.$ dunum/Year $)$ & 450 & 450 \\
WP $\left(\mathrm{Kgs} / \mathrm{m}^{3}\right)$ & 14.51 & 13.76 \\
\hline
\end{tabular}

Source: Statistical analysis.

As shown in table 5, water productivity in solar-powered pumps farms found to be higher than that in diesel-powered pumps farms by almost $5 \%$. This increase could be attributed to better water use efficiency in solar-powered pumps farms compared to diesel-powered pumps farms. This result is in line with a result achieved by Hossain et al. (2015) and Sharif (2013).

\subsection{Financial Indicators}

Table 6 below shows the values of the Net Present Value (NPV), the Internal Rate of Return (IRR), the payback period $(\mathrm{PP})$ and the Benefits to Costs $(\mathrm{B} / \mathrm{C})$ ratio for the investigated farms.

Table 6. WP analysis

\begin{tabular}{lll}
\hline Indicator & Solar-powered pumps farms & Diesel-powered pumps farms \\
\hline NPV (JDs) & 7911.89 & 5731.94 \\
IRR & $55 \%$ & $47 \%$ \\
PP (Months) & 25 & 28 \\
B/C & 1.77 & 1.54 \\
\hline
\end{tabular}

Source: Data analysis. 
As shown in table 6, the NPV values for both types of farms were positive and acceptable. Also, the IRR values in both types of farms indicated that both farms activities provided returns higher than the costs paid. The payback period was less than 2.5 years for both types of farms which is good and acceptable. The B/C ratio was higher than one in both types of farms indicating a viable activity in which the benefits outweighed the actual costs that went in the enterprise. Although all the financial indicators were indicating viable and financially feasible activity, the values of NPV, IRR and B/C ratio were higher in solar-powered pumps farms.

\section{Conclusion and Recommendations}

The results of this study revealed that tomato farms irrigated with solar-powered pumps are economically and financially viable than tomato farms irrigated with diesel-powered pumps. In order to save costs, it is recommended that diesel-powered pumps should be replaced by solar-powered pumps. Government policies and programs should be focused on the concepts of renewable energy in general and using solar systems in agriculture in particular. Special extension plans for training and capacity-building of farmers and extension workers on techniques for using solar energy to irrigate agricultural crops should be developed. Cooperation in the fields of solar energy between the Ministry of Agriculture and related parties such as the Royal Scientific Society and the Ministry of Energy should be initiated to conduct specialized researches in the fields of solar energy use in agriculture.

\section{References}

Abu-Aligah, M. (2001). Design of photovoltaic water pumping system and compare it with diesel powered pump. Jordan Journal of Mechanical and Industrial Engineering, 5, 273-280.

Achkour, A. (2015). Using Solar Energy in Irrigation. Retrieved from http://www.startimes.com/?t=8727511

Alnogrouch, A. (2005). Energy Concepts. Ministry of Energy and Mineral Resources, Jordan.

Bakry, A., \& Jasem, D. (2013). A new Technology to Control and Operate Irrigation Systems Using Renewable Energy Sources. Journal of Babylon University, 21(4).

Campana, P., Li, H., \& Yan, J. (2013). Dynamic modeling of a PV pumping system with special consideration on water demand. Applied Energy, 112, 635-645. https://doi.org/10.1016/j.apenergy.2012.12.073

Campana, P., Li, H., Yan, J., Zhang, J., Zhang, R., \& Liu, J. (2015). Economic optimization of photovoltaic water pumping systems for irrigation. Journal of Energy Conversion and Management, 95, 32-41. https://doi.org/ 10.1016/j.enconman.2015.01.066

Curtis, R. (2010). Economic Feasibility of Solar Photovoltaic Irrigation System Use in Great Basin Forage Production, Utah State Cooperative Extension Proceedings. Utah State University, USA.

DoS (Department of Statistics) (2014). Statistical Survey.

Dursun, M., \& Ozden, S. (2012). Application of solar powered automatic pumping in Turkey. International Journal of Computer and Electrical Engineering, 4(2), 161-164. https://doi.org/10.7763/IJCEE.2013. V5.471

Hahn, A. (2000). Resource-conserving irrigation with photovoltaic pumping systems. 16th European Photovoltaic Solar Energy Conference, Glasgow, UK.

Hossain, M., Hassan, M., \& Mottalib, M. (2015). Feasibility of solar pump for sustainable irrigation in Bangladesh. International Journal of Energy and Environmental Engineering, 6(2), 147-155. https://doi.org/10.1007/s40095-015-0162-4

JRES (Jordan Renewable Energy Society). (2011). Renewable Energy: A promising future and economic saving serving the environment. Amman, Jordan.

Khair, W. (2015). The Importance of Oil for International Economy and the Alternative Strategies for Fuel Sector in Algeria (Master Thesis, Mohamed Khider Biskra University, Algeria). Retrieved from http://thesis.univ-biskra.dz/id/eprint/110

Kjine, J. W., Barker, R., \& Molden, D. (2003). Water Productivity in Agriculture. CABI, Wallingford.

Korpalea, V., Kokatea, D., \& Deshmukha, S. (2016). Performance Assessment of Solar Agricultural Water Pumping System. Energy Procedia, 90, 518-524. https://doi.org/10.1016/j.egypro.2016.11.219

MoA (Ministry of Agriculture). (2014). Annual Report.

Mohammad, M. (2014). Alternative Sources of Power. Jordan Subjects Magazine. Retrieved from http://mawdoo3.com 
NAMREP (Namibia Renewable Energy Programme). (2006). Feasibility assessment for the replacement of diesel pumps with solar pumps (p. 76). Final Report. Ministry of Mines and Energy, Namibia.

Narale, P., Rathore, N., \& Kothari, S. (2013). Study of Solar PV Water Pumping System for Irrigation of Horticulture Crops. International Journal of Engineering Science Invention, 2(12), 54-60.

Neil, N. (2012). Solar Photovoltaic Water Pumping Document. Practical Actions Publications, United Kingdom.

Salameh, E. (2001). Sources of Water Salinities in the Jordan Valley Area, Jordan. Acta Hydrochim. Hydrobiology, 29, 329-362. https://doi.org/10.1002/1521-401X(200112)29:6/7\%3C329::AID-AHEH329\%3 E3.0.CO;2-6

Seham, K., \& Emad, H. (2012). Cost estimation of setting up a solar-powered farm in remote areas. Damascus University Journal for Agricultural Sciences, 28(2), 413-434.

Tietjen, W., Grande, J., Nitzsche, J., Manning, T., \& Dager, E. (2008). Solar pump drip irrigation for vegetable production. ASP Proceedings, Belvidere, NJ.

\section{Copyrights}

Copyright for this article is retained by the author(s), with first publication rights granted to the journal.

This is an open-access article distributed under the terms and conditions of the Creative Commons Attribution license (http://creativecommons.org/licenses/by/4.0/). 